\title{
Lypsylehmien ruokinnan järjestäminen - pitkän aikavälin taloustarkastelu
}

\author{
Risto A. Seppälä ${ }^{1)}$, Timo Sipiläinen ${ }^{1)}$, Matti Ryhänen ${ }^{2)}$, Auvo Sairanen ${ }^{3)}$, Perttu Virkajärvi ${ }^{3)}$, Reetta Palva ${ }^{4)}$ \\ ja Marketta Rinne ${ }^{5}$ \\ ${ }^{1)}$ MTT Taloustutkimus, Luutnantintie 13,00410Helsinki,risto.a.seppala@mtt.fi, timo.sipilainen@mtt.fi \\ ${ }^{2)}$ Seinäjoen AMK, maa-ja metsätalouden yksikkö, Ilmajoentie 525, 60800 Ilmajoki, \\ matti.ryhanen@seamk.fi \\ ${ }^{3)}$ MTT Pohjois-Savon tutkimusasema, Halolantie 31 A, 71750 Maaninka,auvo.sairanen@mtt.fi, \\ perttu.virkajarvi@mtt.fi \\ ${ }^{4)}$ Työtehoseura, Maatalousosasto, PL 13,05201 Rajamäki.reetta.palva@tts.fi \\ ${ }^{5)}$ MTT Kotieläintuotannon tutkimus, Eläinravitsemus, 31600 Jokioinen, marketta.rinne@mtt.fi
}

\section{Tiivistelmä}

Maatilan toimintaa kehitettäessä toimintavaihtoehtojen määrä kytkeytyy suunnittelun aikajänteeseen. Pitkällä aikavälillä on mahdollista tehdä paljon ja suuria muutoksia, mutta lyhyellä aikavälillä vaihtoehtojen määrä voi olla hyvinkin rajoitettu. Kummallakin aikavälillä maatalousyrittäjän tavoitteena on tuottojen ja kustannusten erotuksen maksimointi.

Ruokinta vaikuttaa tuottojen suuruuteen, sillä eri rehuyhdistelmät muuttavat maitotuotoksen määrää ja laatua. Lisäksi niillä on vaikutusta eläinten terveyteen. Maidontuotannossa ruokinta muodostaa keskeisen kustannuserän, joka vaihtelee ruokintavaihtoehdoittain. Kustannukset muodostuvat rehujen hankinnasta, käsittelystä ja eläinten ruokinnasta. Vaihtoehtoiset ruokintateknologiat muuttavat myös kustannussuhteita.

Lehmän ruokinnan ja maitotuotoksen välisen yhteyden selvittäminen on haasteellinen tehtävä, sillä vaihtoehtoisten ruokintakombinaatioiden määrä on suuri ja niiden ravitsemusfysiologiset vaikutukset poikkeavat toisistaan. Haasteellisuutta lisää myös se, että tarkasteluun on otettava mukaan maitotilan omien rehujen tuotanto ja siihen liittyvät prosessit (kasvifysiologia, maatalousteknologia jne.) ja niiden määräämät reunaehdot. Tutkimus on rajattu siten, että siinä tarkastellaan muutamia keskeisimpiä rehuja. Sisäruokintakauden aikana karkearehuna käytetään tilalla tuotettua säilörehua, jota täydennetään väkirehulla (ohra-rypsirouheseos). Kasvukauden aikana kokoaikaisen sisäruokinnan lisäksi vaihtoehtoina on laidunnus tai osittainen laidunnus, sillä laidun on lypsylehmälle luonnollista rehua.

Tässä tutkimuksessa lypsylehmien ruokintaa tarkastellaan pitkän aikavälin taloudellisena optimointiongelmana. Tutkimuksessa luodaan lineaarinen optimointimalli, joka tekee mahdolliseksi tarkastella rehuntuotannon eri osatekijöitä talouden näkökulmasta. Mallilla verrataan eri toimintavaihtoehdoista saatavien tuottojen ja kustannusten erotusta. Optimointimallin pohjana on Seppälän ym. (2002) laatima sisäruokintakauden optimointimalli, joka on päivitetty vastaamaan nykyistä tuotantoteknologiaa ja jota on laajennettu kattamaan myös laidunkausi.

Eri rehuyhdistelmien tuotosvaikutus on määritetty MTT:n tuotantokokeiden pohjalta, kuten mm. vähenevät rajatuotokset ja rehujen väliset korvautuvuussuhteet ja niihin liittyvät rajoitukset. MTT:n koetulosten pohjalta on määritetty säilörehun laadun (D-arvo) ja sadon (kg ka/ha) muutokset kasvukauden edetessä sekä kevätkorjuun ajoittumisen vaikutus syyssadon laatuun ja määrään. Teknologiset mahdollisuudet ja rajoitteet perustuvat pääosin Työtehoseuran tutkimustuloksiin. Laidunkauden osalta responssit perustuvat MTT:n laidunkokeisiin ja TTS:n työnmenekkitutkimusten tuloksiin.

Asiasanat: säilörehu, laidunrehu, taloudellinen analyysi, lineaarinen optimointi 


\section{Johdanto}

Suomen liityttyä Euroopan unionin jäseneksi tuotteiden ja tuotantopanosten hinnat laskivat voimakkaasti, samalla kun kasvi- ja kotieläintuotannon tuet kasvoivat. Muutosten seurauksena optimaaliset panosten käyttömäärät ja niiden keskinäiset käyttösuhteet muuttuivat monilta osin (Ylätalo 1996). Muutosten seurauksena mm. nurmen viljelyn kilpailukyky suhteessa muihin keskeisiin kasveihin huononi. Seppälän ym. (2002) mukaan EU-jäsenyysaikana maatalouspolitiikka ja siinä tapahtuneet muutokset suosivat lypsylehmien ruokinnan suuntaamista aiempaa viljavaltaisemmaksi. Heidän mukaansa säilörehua kannattaa korvata rehuviljasta ja rypsirouheesta tehdyllä kotiseoksella. Maassamme nurmiviljelyala on vähentynyt myös nautaeläinten lukumäärän vähenemisen myötä. EU-jäsenyysaikana nurmiala on vähentynyt noin 20 prosenttia. Lehtosen ja Hirvijoen (2004, s. 79-80) mukaan vuoden 2006 alussa toteutettavan CAP-uudistuksen myötä nautaeläinten ruokinta muuttuu edelleen lievästi väkirehuvaltaisemmaksi vuoden 2002 tilanteeseen verrattuna.

Yrityksen teorian / tuotanto- ja kustannusteorian mukaan maatalousyrittäjän tavoitteena on voiton maksimointi ja / tai kustannusten minimointi siinä toimintaympäristössä, missä hän toimii (mm. Debertin 1986, Varian 1992). Kustannukset voidaan jakaa muuttuviin ja kiinteisiin tarkasteluaikavälin pituuden mukaan. Mitä suurempaa muutosta tavoitellaan, sitä enemmän siitä aiheutuu muuttuvia kustannuksia ja sitä pidemmälle ajalle laskelmien vaikutus ulotetaan. Maatalousyrityksen toimintaa suunniteltaessa potentiaalisten toimintavaihtoehtojen määrä on verrannollinen suunnitteluaikavälin pituuteen.

Pitkällä aikavälillä (5-10 vuotta tai enemmän) on mahdollista muuttaa useita, jopa kaikkia, yrityksen toimintaan vaikuttavia tekijöitä. Esimerkiksi maitotilalla voidaan muuttaa rehujen korjuu- ja käsittelyketjut sekä rakennukset ja rakenteet kokonaan uusiksi. Lyhyen aikavälin toimintaa (esim. kasvukausi, vuosi) suunniteltaessa vain harvoja tekijöitä on mahdollista muuttaa. Tällöin tekijät, joita ei voida muuttaa, asettavat rajoituksia toimintamahdollisuuksille. Esimerkiksi sisäruokintakauden alussa lehmien ruokinnalle asettaa rajoituksia varastossa olevan rehun määrä ja laatu sekä hankittavissa olevien rehujen määrät ja laatu sekä mahdollinen tuotanto- tai budjettirajoite. Näissä puitteissa maidontuottaja pyrkii tuottamaan sisäruokintakaudella mahdollisimman suuren tuottojen ja kustannusten erotuksen.

Tuotanto- ja kustannusteorian mukaan taloudellisesti optimaalinen panosten käyttömäärä ratkaistaan tuotantoteknologian (mekaaniset ja biologiset keinot tuotoksen muodostamiseksi) asettamissa rajoissa panosten ja tuotteiden hintasuhteiden perusteella. EU-jäsenyyden aikana suomalaisten maitotilojen toimintaympäristö on muuttunut suuresti, mikä on vaikuttanut maidontuottajien päätöksiin. Teorian mukaisesti viljan hinnan lasku suhteessa nurmirehun tuotannon yksikkökustannukseen on vaikuttanut päätöksiin. Pahimmillaan väkirehujen hintojen lasku suhteessa nurmirehun yksikkökustannukseen voi johtaa nautaeläinten ruokinnan pois niille biologisesti luonnollisesta ruokinnasta (vrt. Van Soest 1994).

Nautojen ja etenkin lypsylehmien luonnollista rehua ovat nurmikasvit. Lypsylehmä, kuten muutkin märehtijät, ovat kehittyneet evoluution myötä käyttämään ravintonaan heikosti sulavia kasvikuituja, jotka ovat yksimahaisille huonoa tai täysin sopimatonta ravintoa. Käytännön maitotiloilla nurmirehuja täydennetään väkirehuilla. Nurmi- ja väkirehun tuotosvaikutukset ja niiden keskinäinen korvattavuus toisillaan ei ole lineaarista, sillä rehut vaikuttavat toistensa hyväksikäyttöön ruuansulatuksessa (Huhtanen 2004). Kasvukauden aikana nurmisadon määrä ja laatu muuttuvat. Esimerkiksi kasvun edetessä säilörehunurmen hehtaarisato kasvaa mutta nurmen D-arvo alenee. Käytännön tiloilla säilörehun säilönnällinen laatu vaihtelee suuresti.

Taloudellisissa analyyseissä säilörehua ei voida käsitellä homogeenisena tuotteena tai panoksena. Yleensä nurmirehut (säilörehu, laidun) tuotetaan tilalla, jolla se kulutetaan eli niille ei muodostu väkirehun (esim. rehuohran) kaltaista markkinahintaa. Markkinoilla nurmirehumäärät ovat vähäisiä ja paikallisia ja niiden laatu vaihtelee suuresti verrattuna rehuviljoihin. Siksi nurmirehujen hinta johdetaan niiden tuottamisesta aiheutuvista kustannuksista. Ne ovat sidoksissa korjuu-, varastointi-ja ruokintateknologiaan, mikä vaikuttaa tilalle valittavaan tuotantoteknologiaan. Edellä esitetyssä viitekehyksessä laitumen ja säilörehun tuotannon taloudellinen tarkastelu on tehtävä lopputuotteen, maidon, tuotannon taloudellisen optimoinnin yhteydessä. Perinteisen tuotanto- ja kustannusteoreettisen mallintamisen lähtökohdista käytännön tutkimusongelmien ratkaiseminen on erittäin haasteellinen tehtävä (ks. mm. Fagerberg ja Torssell 1990). Kun tutkitaan tuotantoympäristössä tapahtuvien huomattavien muutosten seurauksia käytännön maidontuotantoon tilatasolla, tutkimusongelman ratkaisemiseen tarvitaan biologis-fyysisistä riippuvuussuhteista lähtevää tarkastelua, sillä se sopii siihen tai se on jopa ainoa mahdollinen keino saada oikeita vastauksia (vrt. Rotz ym. 1989; Torssel ja Fagerberg 1990; Berentsen ja Giesen 1995; Ryhänen 1996; DeLorenzo ja Tho- 
mas 1996; Seppälä ym. 2002).

Tässä tutkimuksessa tarkastellaan maitotilan nurmirehuntuotantoa pitkän aikavälin strategisena päätöksenä. Tutkimuksessa haetaan vastausta siihen, miten maitotilan peltoviljely säilörehun ja laitumen osalta on järjestettävä, jotta koko maitotilan toiminta johtaa parhaimpaan mahdolliseen taloudelliseen tulokseen. Edellisen lisäksi maidontuottajan on pitkän aikavälin tuotantotoiminnan suunnittelussa oleellista tietää:

1. millaisella rehuyhdistelmällä lypsylehmät kannattaa ruokkia sisä- ja laidunruokintakaudella,

2. miten rehuntuotanto tilalla järjestetään optimaalisesti ja

3. millainen on laiduntamisen kilpailukyky suhteessa jatkuvaan sisäruokintaan.

\section{Aineisto ja menetelmät}

Maidontuotannon taloudellisen toiminnan optimoinnissa tarvitaan tietoa nurmen kasvusta, lehmän kyvystä muuntaa rehua maidoksi ja tuotantoteknologian antamat mahdollisuudet tuotantotoiminnassa. Nurmen sadon määrän ja rehuarvon kehityksestä, säilörehun korjuuteknologiavaihtoehdoista, laidunnustavoista ja niiden vaikutuksista tuotantomääriin ja työmenekkiin saadaan tietoa Maa- ja elintarviketalouden tutkimuskeskuksen (MTT) ja Työtehoseuran (TTS) tuottamista aineistoista.

Seppälän ym. (2002) tuottama säilörehun tuotantomalli ja sen aineisto otetaan käyttöön siten, että malli päivitetään vastaamaan uutta teknologiaa ja malliin kytketään mukaan laidunkausi. Mallia ajanmukaistetaan siten, että tuotantoketjujen ja -menetelmien vaatimat uudet parametrit määritetään TTS:ssä tutkimustulosten ja työnormien perusteella (Peltonen ym. 2003, Karttunen ym. 2004, Karttunen 2004). MTT on tuottanut väkirehun ja laidunrehun syöntiin sekä maitotuotokseen liittyvät parametrit niin, että ne voidaan kytkeä toisiinsa biologis-teknisen tiedon pohjalta. Se muodostaa tuotantomahdollisuuksien joukon, joka on optimoinnin rajoitejoukko. Säilörehun satotaso ja rehuarvo määritetään Rinteen ym. (2000) ja Kuoppalan ym (2004) havaintojen perusteella vuosilta 1998-2000 ja 2002. Laidunnurmen satotiedot ja laidunrehun maitotuotosresponssi perustuvat MTT:n Pohjois-Savon tutkimusasemalla tehtyihin tutkimuksiin (esim. Sairanen ja Virkajärvi 2002). Laiduntamisen työmenekki saadaan Palvan (2005) tutkimuksesta.

Aineistoa on jouduttu kokoamaan eri puolilla Suomea ja koeaineistojen sadot ylittävät yleensä käytännön tilojen sadot, joten koeaineistot muunnetaan vastaamaan toisiaan ja lopulta käytännön tilojen satotasoa. Käytännön satotason referenssipisteeksi on valittu Jokioinen, koska säilörehuaineisto on tältä paikkakunnalta. Jokioinen sijaitsee B-tukialueella, joten koetulokset suhteutetaan tämän alueen MKL:n Hilatilojen mediaanien perusteella. Laitumen osalta paikkakuntien välinen ero on otettu huomioon nurmen kasvukautta pidentämällä. Laidunnurmen D-arvo ja hyväksikäyttöprosentti määritetään vastaamaan käytännön tilojen tuloksia. Laskelmissa käytetään vuoden 2004 hintatasoa.

LP-mallissa tavoitefunktiona on maitotuoton ja rehukustannuksen erotuksen maksimointi (kaava 1). Ylijäämä lasketaan maitotuoton ja rehukustannuksen erotuksena siten, että rehukustannukseen sisältyvät kaikki rehujen hankkimiseen liittyvät kustannukset. Laidunkauden ruokinta kytketään malliin vaihtoehtoisina laidunnusmuotoina. Rehukustannus muodostetaan pitkän aikavälin taloussuunnittelun näkökulmasta. Tällöin kaikki rehujen tuotantoon / hankintaan liittyviä tekijät ovat muuttuvia. Mallissa oletetaan tilan erikoistuneen kotieläintuotannon osalta pelkästään maidontuotantoon. Tilan peltoalasta $3 / 4$ osaa on nurmella (säilörehua tai laidunta) ja loppuosa nurmen uudistusalalla viljeltävää rehuviljaa. Sisäruokintakauden mallin rakenne on esitetty yksityiskohtaisesti Seppälän ym. (2002) tutkimuksessa.

Vaihtoehtoja arvioidaan lopputuotteen (maidon) tuotannon kautta. Ruokintasuunnitelmissa on otettu huomioon syönnin, rehun laadun ja maitotuotoksen yhteys. Poikimisajankohdan vaikutusta ei tutkita. Säilörehun tuotanto ja kulutus vastaavat karjan sisä- / laidunruokintakauden tarvetta. Oletus tehtiin, koska maidontuotantoa ei nykyisellään voida perustaa ostonurmirehujen varaan eikä säilörehun ja laitumen laajamittaiselle kaupalle ole ollut edellytyksiä. 


$$
\begin{aligned}
\max z= & p \sum_{i=a}^{t} x_{i} y_{i}+p \sum_{i=a}^{t} \sum_{j=1}^{r} x_{i j} y_{i j}+\left(A-R-w_{v}\right) \sum_{i=a}^{t} H_{i}^{k}-\sum_{i=a}^{t} w_{i} x_{i} \\
& -\sum_{i=a}^{t} \sum_{j=1}^{r} w_{j} x_{i j}-w_{c}\left(x_{c}^{k}+x_{c}^{S}\right)-F-G-U \\
& +p D^{L} y^{l} n-n\left(D^{L} w^{L}+w^{\Delta L S}+w_{j t}+w_{c}^{l}\right)-w_{a i} P_{\max }
\end{aligned}
$$

ehdoilla, että
1) $\sum_{i=a}^{t} \sum_{j=1}^{r} H_{i j}^{S}=\sum_{i=a}^{t} H_{i}^{k}$
2) $\sum_{i=a}^{t} H_{i}^{k}+P=3 V$
3) $H_{i}^{k}=\sum_{j=1}^{r} H_{i j}^{S}$
4) $x_{i} l_{i} \leq L_{d}$
5) $x_{i j} l_{i j} \leq L_{d}$
6) $\sum_{i=a}^{t} x_{i j} l_{i j} \leq L_{d}$
7) $x_{i}=n f_{i} D_{i}$
8) $x_{i j}=n f_{i j} D_{i j}$
9) $x_{c}^{k}=n \sum_{i=a}^{t} x_{c i}^{d} D_{i}$
10) $x_{c}^{s}=n \sum_{i=a}^{t} \sum_{j=1}^{r} x_{c j}^{d} D_{i j}$
11) $\sum_{i=a}^{t} D_{i}+\sum_{i=a}^{t} \sum_{j=1}^{r} D_{i j}=205$

12) $\sum_{i=a}^{t} H_{i}^{k}=\sum_{i=a}^{t} \sum_{j=1}^{r} H_{i j}^{S}+\sum_{i=a}^{t} \Delta P_{i}$

13) $\mathrm{P}+\sum_{i=a}^{t} \Delta P_{i}=P_{\max }$

14) $\sum_{i=a}^{t} D_{i}+\sum_{i=a}^{t} \sum_{j=1}^{r} D_{i j}+D^{L}=300$

$\mathrm{z} \quad=$ ylijäämä, $€$

$\mathrm{p}=$ maidon hinta + hintatuki, $(€ / \mathrm{kg})$

$\mathrm{x}_{\mathrm{i}}=$ säilörehun korjattu määrä kunakin kevätkorjuupäivänä ( $\mathrm{kg} \mathrm{ka}$ ); hävikit vähennetty

$\mathrm{y}_{\mathrm{i}}=$ tietyllä etukäteen valitulla väkirehutasolla ( $\mathrm{kg} \mathrm{ka}$ ) ja tietyllä kevätsäilörehun D-arvolla (kunakin korjuupäivänä) tuotettu maitomäärä ( $\mathrm{kg} / \mathrm{säilörehun} \mathrm{kg} \mathrm{ka})$

a $=$ kevätkorjuun aloituspäivä

$\mathrm{t} \quad=$ kevätkorjuun lopetuspäivä

$\mathrm{x}_{\mathrm{ij}}=$ säilörehun korjattu määrä tiettyä kevätkorjuupäivää (i) vastaavana syyskorjuupäivänä (j) (kg ka)

$\mathrm{y}_{\mathrm{ij}}=$ tietyllä etukäteen valitulla väkirehumäärällä ( $\mathrm{kg} \mathrm{ka}$ ) ja tietyllä syyssäilörehun D-arvolla (kutakin kevätkorjuupäivää (i) vastaavana syyskorjuupäivänä (j) korjattu rehu) tuotettu maitomäärä (kg/säilörehun kg ka)

r = kutakin kevätkorjuupäivää vastaavat syyskorjuupäivät

$\mathrm{A}=$ suora tuki yhteensä $(€ / \mathrm{ha})$

$\mathrm{P}$ = laidunala (ha)

$\mathrm{V}=$ vilja-ala (ha)

$\mathrm{H}_{\mathrm{i}}^{\mathrm{k}}=$ tiettynä kevätkorjuupäivänä korjattu säilörehuala, ha; $\left(\mathrm{H}_{\mathrm{i}}^{\mathrm{k}}=\mathrm{x}_{\mathrm{i}} /\right.$ ha-sato $)$

$\mathrm{H}_{\mathrm{ij}}{ }^{\mathrm{s}}=$ tiettyä kevätkorjuupäivää (i) vastaavana syyskorjuupäivänä (j) korjattu säilörehuala, ha; $\left(\mathrm{H}_{\mathrm{ij}}{ }^{\mathrm{s}}=\mathrm{x}_{\mathrm{ij}} / \mathrm{ha}\right.$ sato)

$\mathrm{w}_{\mathrm{i}}=$ tuotetun säilörehun määrän mukaan muuttuvat yksikkökustannukset kevätrehulla $(€ / \mathrm{kg} \mathrm{ka})$

$\mathrm{w}_{\mathrm{j}}=$ tuotetun säilörehun määrän mukaan muuttuvat yksikkökustannukset syysrehulla (€/kg ka)

$\mathrm{F}=$ säilörehukoneista ja kalustosta aiheutuva vuotuiskustannus (€/tila) 
$\mathrm{G}=$ siilon peittämisen työkustannus $(€)$

$\mathrm{U}=$ siilorakennuksen vuotuiskustannus ja muovikustannus $(€)$

$\mathrm{R}$ = pellon kustannus, $€ /$ ha (salaojien vuotuiskustannus ja pellon korko / vuokra)

$\mathrm{w}_{\mathrm{v}}=$ vakio nurmen perustamis- ja lannoituskustannus sekä liikepääoman korko $(€ / \mathrm{ha})$

$\mathrm{w}_{\mathrm{c}}=$ väkirehun hinta $(€ / \mathrm{kg} \mathrm{ka})$

$\mathrm{x}_{\mathrm{c}}{ }^{\mathrm{k}}=$ väkirehun määrä kevätsäilörehua syötettäessä $(\mathrm{kg} \mathrm{ka})$

$\mathrm{x}_{\mathrm{c}}{ }^{\mathrm{s}}=$ väkirehun määrä syyssäilörehua syötettäessä $(\mathrm{kg} \mathrm{ka})$

$l_{\mathrm{i}}=$ työnmenekki tiettynä kevätkorjuupäivänä (tuntia/kg ka)

$1_{\mathrm{ij}}=$ työnmenekki tiettyä kevätkorjuupäivää (i) vastaavana syyskorjuupäivänä (j) (tuntia/kg ka)

$\mathrm{L}_{\mathrm{d}}=$ käytettävissä oleva työn määrä korjuupäivää kohti (tuntia)

$\mathrm{f}_{\mathrm{i}} \quad=$ kutakin kevätkorjuupäivää vastaavan säilörehun syönti (kg ka/päivä/lehmä)

$\mathrm{f}_{\mathrm{ij}}$ = kutakin kevätkorjuupäivää (i) vastaavana syyskorjuupäivänä (j) korjatun säilörehun syönti (kg $\mathrm{ka} / \mathrm{päivä/lehmä)}$

$D_{\mathrm{i}}=$ kutakin kevätkorjuupäivää vastaavan säilörehun syöntiaika (vrk)

$\mathrm{D}_{\mathrm{ij}}=$ kutakin kevätkorjuupäivää (i) vastaavana syyskorjuupäivänä (j) korjatun säilörehun syöntiaika (vrk)

$\mathrm{x}_{\mathrm{ci}}{ }^{\mathrm{d}}=$ väkirehun syönti kevätsäilörehulla (kg ka/päivä/lehmä)

$\mathrm{x}_{\mathrm{cj}}{ }^{\mathrm{d}}=$ väkirehun syönti syyssäilörehulla ( $\mathrm{kg} \mathrm{ka/päivä/lehmä)}$

$\mathrm{n} \quad=$ lehmämäärä

$\mathrm{D}^{\mathrm{L}}=$ Laidunruokinnalla oltavat päivät (vrk)

yl = Laidunruokinnalla saatava maitotuotos (vrk/lehmä)

$\mathrm{w}^{\mathrm{L}}=$ laiduntamisen työkustannus (lehmien siirrot, syöttölohkojen siirto, vesihuolto $€ /$ vrk/lehmä)

$\mathrm{w}^{\Delta \mathrm{LS}}=$ kesäkauden sisäruokinnan edellyttämä lietesäiliön ja lietteen käsittelyn kustannus (€/lehmä)

$w_{j t}=$ kesäkauden sisäruokinnan edellyttämän jaloittelutarhan (parsinavetat) kustannus

$w_{c}^{l}=$ laidunnurmea täydentävän väkirehun kustannus

$w_{a i}=$ laitumen reunan aitauskustannus $€ /$ ha

$P_{\max }=$ suurin syyskesällä käytettävä laidun ala (=varsinainen laidunala + laitumeksi otettava säilörehun nurmen odelma ha)

$\Delta P=$ laitumeksi otettava säilörehun nurmen odelma (ha)

Rajoitteiden selitykset:

1. Säilörehun kevät - ja syyskorjuuala määritetään yhtä suureksi.

2. Vilja-ala on yhtä suuri kuin nurmen uudistusala. Nurmet ovat kolmevuotisia.

3. Tiettyä kevätkorjuupäivää vastaavina syyskorjuupäivinä korjattavan nurmialan on oltava yhtä suuri kuin kyseisenä kevätkorjuupäivänä korjatun nurmialan. Rajoite tarvitaan, jotta tiettyä kevätkorjuupäivää vastaavan syyssadon laatu ja määrä saadaan kytkettyä kyseiseen kevätkorjuupäivään. Näin varmistetaan, että syyskorjuussa saatava sadon määrä ja laatu vastaavat tietyn kevätkorjuupäivän jälkeisen sadon määrää ja laatua.

4. Säilörehun korjuun päivittäinen työnmenekki ei saa ylittää säilörehun kevätkorjuun aikana käytettävissä olevaa päivittäistä työaikaa.

5. Säilörehun korjuun päivittäinen työnmenekki ei saa ylittää säilörehun syyskorjuun aikana käytettävissä olevaa päivittäistä työaikaa.

6. Eri kevätkorjuupäiviä vastaavana samana syyskorjuupäivänä tehdyn työn määrä ei saa ylittää käytettävissä olevaa päivittäistä työaikaa. Rajoite estää eri kevätkorjuupäiviä vastaavien syyskorjuupäivien sijoittamisen samalle syyskorjuupäivälle siten, että päivittäinen enimmäistyöaika ylittyisi. Rajoite ei estä eri kevätkorjuupäivien syyskorjuun sijoittumista samalle syyskorjuupäivälle, jos korjuu tapahtuu työaikarajoitteen puitteissa. 
7. Keväällä korjatun säilörehun päivittäisen syönnin, syöntipäivien ja lehmämäärän tulon on oltava yhtä suuri kuin keväällä korjatun säilörehusadon määrä (väkirehutaso ja säilörehun D-arvo kiinnitetty etukäteen).

8. Syksyllä korjatun säilörehun päivittäisen syönnin, syöntipäivien ja lehmämäärän tulon on oltava yhtä suuri kuin syksyllä korjatun säilörehusadon määrä (väkirehutaso ja säilörehun D-arvo kiinnitetty etukäteen).

9. Kevätsäilörehua syötettäessä ennalta määrätyn väkirehutason, syöntipäivien ja lehmämäärän tulon on oltava yhtä suuri kuin kevätsäilörehun syöntiaikana syötettävän väkirehun määrä.

10. Syyssäilörehua syötettäessä ennalta määrätyn väkirehutason, syöntipäivien ja lehmämäärän tulon on oltava yhtä suuri kuin syyssäilörehun syöntiaikana syötettävän väkirehun määrä.

11. Kevät- ja syyssäilörehun syöntipäivien summan on oltava yhtä suuri kuin sisäruokintakauden tuotospäivien lukumäärä.

12. Kevätkorjuun säilörehuala on yhtä suuri kuin syyskorjuun säilörehualan ja laitumeksi otettavan kevätkorjuun odelman summa (ha)

13. Suurin syyskesällä käytettävä laidunala on varsinaisen laidunalan ja laitumeksi käytettävän laidunalan summa

14. Sisäruokinta- ja laidunkauden tuotospäiviensumma on 300 vuorokautta

LP-malli laadittiin olettaen, että säilörehusato ja sen laatu (D-arvo) muuttuvat päivittäin, mutta ovat vakioita kunakin päivänä. Kevätkorjuu oletetaan tehtävän yhtäjaksoisesti. Säilörehun korjuupäivä (laatu), kyseisen rehun syönti ja maitotuotos on määritetty portaittain eri väkirehutasoille. Säilörehun määrä sopeutetaan vastaamaan kyseistä tuotostasoa vastaavaa tarvetta. Ruokinnan rajoitteena on säilörehun NDFkuidun osuus koko rehuannoksessa siten, että säilörehusta peräisin olevan NDF-kuidun osuus ei saa olla alle 25 prosenttia. Säilörehun hehtaarisato ja D-arvo kytketään korjuuajankohtaan ja -kapasiteettiin. Tilussuhteiden vaikutus sisällytetään malliin pellon ja talouskeskuksen keskimääräistä etäisyyttä kuvaavalla muuttujalla. Työkoneiden työsaavutusta voidaan muuttaa tarpeen mukaan. Mallissa oletetaan, että nurmea kasvatetaan viljelykierron mukaisesti kaikilla lohkoilla.

Väkirehutaso on määritetty erikseen kevät- ja syyssäilörehua varten, joten väkirehutaso voi olla erilainen kevät- ja syysrehulla. Säilörehun D-arvon muutokset vaikuttavat lehmän päivittäin tarvitsemaan säilö- ja väkirehumäärään ja maitotuotokseen.

\section{Tulokset ja tulosten tarkastelu}

Malli antaa tulokseksi lypsylehmien optimaalisen pitkän aikavälin ruokintastrategian. Annetuilla tiedoilla se ratkaisee esimerkiksi optimaalisen säilörehun, laidunrehun ja väkirehun käyttömäärät. Lisäksi se tuottaa tietoa päätöksenteon tueksi mm. siitä, miten säilörehun korjuu kannattaa järjestää tulevaisuudessa, onko säilörehun korjuukoneiden yhteiskäyttö, urakointi vai oma koneketju edullisin vaihtoehto tilan olosuhteissa. Malli antaa myös taloudellisin perustein suosituksen, millä D-arvolla kevät- ja syyssäilörehusadon korjuu kannattaa toteuttaa, jotta korjuu tapahtuisi talouden näkökulmasta optimaalisella ajankohdalla. Mallilla on mahdollista myös verrata eri laiduntamisvaihtoehtoja (ei laidunnusta, osittaislaidunnus tai ympärivuorokautinen laidunnus). Mallilla voidaan selvittää lisäksi, miten paljon edellä olevat tekijät tai niiden vaihtelut vaikuttavat tuottojen ja kustannusten erotukseen. Mallia voidaan käyttää edistyksellisten tilojen tuotannon suunnitteluun, jos tilalta on saatavissa riittävässä määrin riittävän tarkkaa aineistoa lähtötiedoiksi.

\section{Johtopäätökset}

Mallin avulla on mahdollista tutkia, miten lypsylehmän dieettiä kannattaa muuttaa, kun taloudellisessa toimintaympäristössä tapahtuu suuria muutoksia. Se on hyvä apuväline strategiseen suunnitteluun maitotilalla. Se mahdollistaa säilörehun korjuutekniikkavaihtoehtojen ja tilojen välisen yhteistyön tai urakoinnin sekä erilaisten laidunnusratkaisujen tarkastellun ja niiden vaikutuksen maitotilan taloudelliseen tulokseen.

Tuloksia sovellettaessa käytäntöön on kuitenkin tiedostettava, että maidontuotanto koostuu kokonaisuudesta, jonka muodostavat mm. peltoala, sen laatu ja saatavuus, lehmien laidunnusmahdollisuus, pellon ja lehmien tuottokyky, koneketjut sekä monet muut tilakohtaisesti määräytyvät tekijät. Niillä on 
vaikutusta tilakohtaisiin valintoihin. Siten tilakohtaisten laskelmien laadinta on oleellista. Jos tilakohtaisia laskelmia ei ole mahdollista laatia, aluetta kuvaavien laskelmien laatiminen omaan tilaan soveltaen antaa pohjaa tilakohtaiselle suunnittelulle. Mallin käytön edellytyksenä käytännön tiloilla on se, että tiloilla on riittävä määrä tietoa nurmisadon kehityksestä tilan oloissa.

Mallia käytettäessä on keskeistä tiedostaa lyhyen ja pitkän aikavälin suunnitelmien ero. Pitkän aikavälin eli strategisen suunnittelun lisäksi tilalla tehdään lähes päivittäin lyhyen aikavälin päätöksiä. Lyhyen aikavälin suunnittelussa säilörehun hintana käytetään muuttuvaa yksikkökustannusta kokonaisyksikkökustannuksen sijasta, koska kiinteät kustannukset ovat ns. uponneita kustannuksia, joihin suunnitteluaikavälillä ei voida vaikuttaa.

\section{Kirjallisuus}

Berentsen, P.B.M. \& Giesen, G.W.J. 1995. An environmental-economic model at farm level to analyse institutional and technical change in dairy farming. Agricultural Systems 49: 153-175.

Debertin, D.L. 1986. Agricultural production economics. New York. $366 \mathrm{~s}$.

DeLorenzo, M.A. \& Thomas, C.V. 1996. Dairy records and models for economic and financial planning. Journal of Dairy Science 79: 337-345.

Fagerberg, B. \& Torssell, B.W.R. 1990. Harvest time predictions in leys. 2. Economic consequences of harvest time at two contrasting feeding strategies. Swedish Journal of Agricultural Research. 20: 11-18.

http://www.smts.fi/MTP\%20julkaisu\%202004/esi04/ti54.pdf

Huhtanen, P. 2004. Dynaaminen rehuarvomalli tarkentaa ravintoaineiden saannin ennustetta. Maataloustieteen päivät 2004. Suomen Maataloustieteellisen Seuran tiedote no 20. 43.

Karttunen J. 2004. Maidontuottajien teknologiavalinnat suurissa tuotantoyksiköissä - Karkearehun käsittelyketjut ja karjanhoitotöiden työnmenekki. (Choice of technology on large dairy farms) Työtehoseuran julkaisuja 394. Helsinki. $73 \mathrm{~s}$.

Karttunen, J., Peltonen, M. \& Pentti S. 2004. Säilörehun korjuuketjun suunnittelu - rehuketjun kustannukset ja pullonkaulojen minimointi. Työtehoseuran Maataloustiedote 5/2004 (568). $8 \mathrm{~s}$.

Kuoppala, K., Rinne, M., Nousiainen, J. \& Huhtanen, P. 2004. Säilörehun ensi- ja jälkikasvun korjuuajan sekä väkirehutäydennyksen vaikutus lypsylehmien maidontuotantoon. Maataloustieteen päivät 2004. Esitelmä- ja posterilyhennelmät. Suomen Maataloustieteellisen Seuran tiedote no 20.

Lehtonen, H. \& Hirvijoki, M. 2004. CAP-uudistuksen vaikutukset maidontuotantoon. MTT:n selvityksiä 62: 66-85.

Palva, R. 2005. Lehmien laiduntamisen työnmenekki. Työtehoseuran Maataloustiedote, kotieläintuotanto. 7/2005, (580). $8 \mathrm{~s}$.

Peltonen, M., Karttunen, J. \& Pentti S. 2003. Säilörehunkorjuun työnmenekki - korjuumenetelmät ja toiminnallisuus. Työtehoseuran Maataloustiedote 9/2003 (560). $12 \mathrm{~s}$.

Rinne, M., Hellämäki, M., Nousiainen, J., Aura, E. \& Huhtanen, P. 2000. Kevätkorjuun optimoinnista koko kesän nurmisadon hallintaan. Maataloustieteen päivät 2000. Kotieläintiede. Maaseutukeskusten liiton julkaisuja 952: 126-129.

Rotz, C.A., Black, J.R., Mertens, D.R. \& Buckmaster, D.R. 1989. DAFOSYM: A Model of the Dairy Forage Systems. Journal of production agriculture 2: 83-91.

Ryhänen, M. 1996. Maatalousyrittäjän päätöksenteko. Teoksessa Ylätalo M. (toim.) Maatalousyritysten sopeutuminen EU:ssa vallitseviin hintasuhteisiin. Tuotanto- ja kustannusteoreettinen tarkastelu kasvinviljelyyn ja kotieläintuotantoon sovellettuna. Helsingin yliopisto. Taloustieteen laitos. Julkaisuja 12: 9-23.

Sairanen, A. \& Virkajärvi, P. 2002. Lypsykarjan laiduntaminen. Teoksessa: Laiduntaminen kannattaa. Tieto tuottamaan 99. ProAgria Maaseutukeskusten Liiton julkaisuja 984: 46-70.

Seppälä, R., Ryhänen, M, Sipiläinen, T., Rinne, M., Huhtanen, P. \& Suokannas, A. 2002 Säilörehu maitotilan taloudessa -pitkän aikavälin näkökulma. Teoksessa Ryhänen, M. \& Sipiläinen, S. (toim.) Nurmisäilörehu maitotilan taloudessa.

Torssell, B.W.R. \& Fagerberg, B. 1990. Predicting economic optimum and nitrogen balance in the ley - ru-minant system. Swedish University of Agricultural Sciences. Department of Crop Production Science. Crop Production Science 10: 1-45.

Van Soest, P.J. 1994. Nutritional ecology of the ruminant. 2 nd. ed. New York. 476 p.

Varian, H.R. 1992. Microeconomic Analysis. W.W.Norton \& Company, New York. 506 s.

Ylätalo M. (toim.). 1996. Maatalousyritysten sopeutuminen EU:ssa vallitseviin hintasuhteisiin. Tuotanto- ja kustannusteoreettinen tarkastelu kasvinviljelyyn ja kotieläintuotantoon sovellettuna. Helsingin yliopisto. Taloustieteen laitos. Julkaisuja 12: 9-23. 